\title{
ホームユースロボット の技術と課題
}

on

ロボット，ネットワーク，情報家電，インタフェース

オープンアーキテクチャー

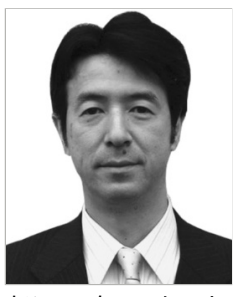

松日楽 信人

\section{1.はじめに}

最近，いろいろな種類のホームユースロボットが開発さ れている。産業用ロボットや原子力・宇宙など特殊環境下 でのロボットから，その応用分野は医療福祉など身近な環 境へと変化している。ペットロボット，ビル掃除・警備ロ ボット，低価格な掃除ロボット，留守番ロボットはすでに 製品化され，少しずつ市場が出来始めている(1)(2)。さらに ブロードバンド環境の普及に伴い，家庭内でも家電を初め 各種機器がネットワークにつながれ，ホームネットワーク の構築が進んでいくと予想される。ロボットはユビキタス 社会における“動く端末”として新しい製品への応用が期 待されている。一方近年は，少子高齢化，情報ネットワー ク化，セキュリティなど社会的な環境が大きく変化してお り，これらにおける不安要因に対してロボット技術 （RT）への期待も大きい。本稿では東芝で開発している

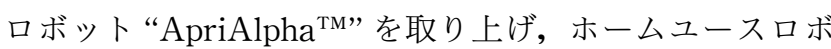
ットの技術と課題について紹介する ${ }^{(3)}$ 。

\section{2. ホームユースロボットへの期待と機能}

パートナーロボットの用途別希望購入価格調査 ${ }^{(4)}$ によ ると，いやし系ロボット 10 万円未満，留守番・警備系ロ ボット 20 万円未満，介護系ロボット 30 万円未満，家事手 伝い系ロボット 30 万円未満という結果がある。これはい わゆるロボットというよりは家電の価格であり，ユーザは 家電としてロボットをとらえている。そして，ロボットに 期待する役割として, 留守番・警備, 掃除・家事手伝い, また，機能としては，力仕事，家電制御，賢さが挙げられ ている。まだまだ期待と実現できる機能，およびコストと

まつひら・のぶと 1982 年東京工業大学大学院理工学研究 科修士課程修了。同年東京芝浦電気(株)（現東芝）入社。原子 力, 宇宙, 医療, 家庭応用などロボットシステムの研究開発に 従事。(株) 東芝研究開発センター研究主幹, 東京工業大学 21 世紀 COE プログラム特任教授。計測自動制御学会, 日本ロボ ット学会の会員。日本機械学会フェロー。工学博士。
のギャップは大きいが，実用的であれば高価格でも購入を 検討する消費者の多いことも調査結果にある。さらに，ネ ットワークとの連携によりロボットの市場は大きくなると 期待され，2013 年にはロボット応用で 3.5 兆円だが，ネ ットワークサービス関連も含めると 19.8 兆円と見込まれ ている(5)。

一方, 家庭など生活支援面でのロボットの応用は, (1)物 理的な支援（人の動作を直接支援するもの，人へものを持 ってくるもの)，(2)間接的な支援（人とは独立して動いて いるもの)，(3)情報としての支援（情報をやり取りするも の), に大きく分類される(6)。人と物理的なインタラクシ ヨンを伴うものや, 独立して動いているものとは言え, 作 業を行うものは制度も含めて安全性や自律性の観点からそ う簡単には実現できない。したがって，家庭内環境では人 とは直接のインタラクションの少ないクリーナロボットや 留守番監視ロボット, 情報端末ロボットの開発が多くな る。産業用ロボットでは環境や作業内容が定型のものが多 いので, 自律的に作業を行うことができる。原子力など特 殊分野も，ロボットが保守しやすい環境や構造に対象物も 設計できるので自動化が可能である。ただし, 非定型な作 業に関しては人が操作する遠隔操作ロボットが用いられて いる。このように先行している分野を見ても，自律的に一 連の作業を行っているロボットは少なく, 実用的なものは “見に行く”という作業から始まっている。ホームユース においても同様なことが言えるだろう。

\section{3. ホームユースロボットとオープン化}

\section{1 ロボット情報家電のコンセプト}

ホームユースロボットで期待されている代表的な機能 は，掃除などの実作業を除くと，“コミュニケーション機 能”, “情報家電機能”, “セキュリティ機能”である。すな わち，だれでもが簡単にネットワークにつながった機器を 操作できるためのインタフェースとしての役割と，家族が 留守の間に家の様子を見たり, 介護の必要な高齢者や病人 の様子を見守る移動型カメラとしての役割である。このよ 


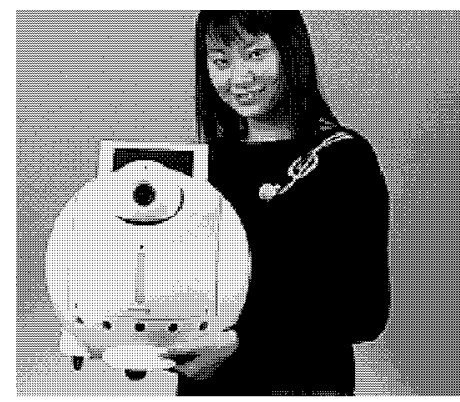

\begin{tabular}{|c|c|}
\hline \multirow{3}{*}{ 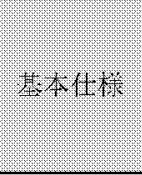 } & 人きさ泊径 $\phi 350 \times$ 宲さ $380 \mathrm{~mm}$, 質黾約 $9.5 \mathrm{~kg}$ \\
\hline & 月·耳・山:ズーム付きCCDカメラ, マイタ, スピーカ, TFT液品モニ夕 \\
\hline & 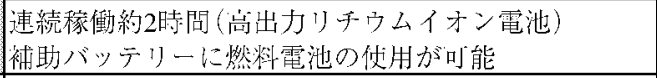 \\
\hline \multirow{3}{*}{$\begin{array}{c}\text { コミュニ } \\
\text { ケーション } \\
\text { 機能 }\end{array}$} & 声で指示 (音声認識) し，話してくれる(音声合成) \\
\hline & 声・咅の検知, 離れた所から呼びかけに応答 $(\sim 3 \mathrm{~m})$ \\
\hline & 顔の検出·距離測定 $(-3 \mathrm{~m})$, 顔の認識 (約 100 人対伈) \\
\hline \multirow{2}{*}{ 通伝粠能 } & 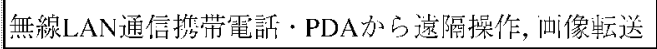 \\
\hline & 赤外線リモコンで家雷操作, ホームサーバ/ネ外家需と連㧥 \\
\hline \multirow{2}{*}{ 建動栋能 } & 移動速度 $0.5 \mathrm{~m} / \mathrm{s}$, 超省波センサで障害物を吅避 \\
\hline & 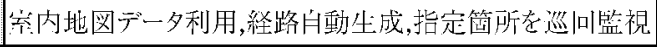 \\
\hline
\end{tabular}

図 1 ロボット情報家電 ApriAlpha ${ }^{\mathrm{TM}}$ と光の仕様

うな家庭での機能をイメージし，人とネットワーク機器と のインタフェースとして図 1 亿示すロボット情報家電のコ ンセプトモデル ApriAlpha ${ }^{\mathrm{TM}}$ を開発した。このロボット は研究開発のためのプラットフォームとして構築され，さ まざまな機能や要素技術を搭載して検証することを目的と している。さらに, ホームユースでは家電のように複数社 のロボット製品が混在する可能性がある。したがって, 普 及にはいかに簡単にシステム化ができるか, 家庭内で共通 の仕様で利用できるか，という開発側と利用側からの課題 がある。

\section{2 オープンロボットコントローラアーキテクチャー}

ロボットはシステムであり, ApriAlpha ${ }^{\mathrm{TM}}$ の場合も, 図 2 亿示すように音声, 画像, 運動制御, 通信技術などを統 合したシステムとして成り立っている。そこで, 分散オブ ジェクト技術(7)を用い, これら個及の技術をモジュール 化し，インタフェースを標準化することで簡単に組み込み が可能となるような枠組みとしてオープンロボットコント ローラアーキテクチャー（ORCA）を開発している。例え ば，ロボット以外の分野で開発されているカーナビなどの 音声処理技術や，セキュリティ管理での顔認証技術などの ソフトウェアエンジンをベースに，ロボット用にチューニ ングして取り込むことが可能となり，開発効率を向上させ ている。ただし，ロボットではそのままでは使えず，離れ た場所からでも音声認識できるように指向性を利用したマ

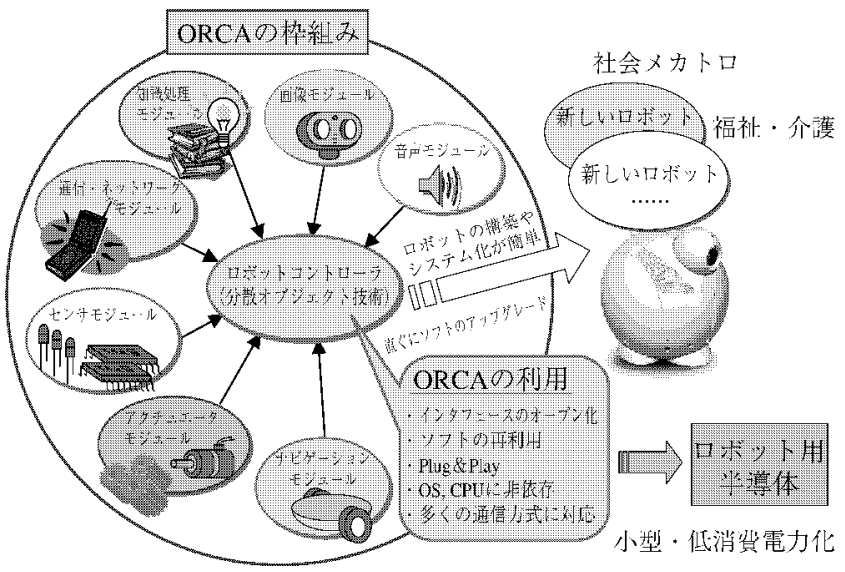

図 2 ApriAlpha $^{\mathrm{TM}}$ とコントローラアーキテクチャー

イクアレーの技術や，背景や照明に依存しにくく，かつ複 数同時の顔検出・認識技術などに発展させる必要がある。

このようなアーキテクチャーとすることでソフトウェア のアップグレードやモジュール交換により, ロボット自身 の性能向上だけでなく新機能のロボットが実現される。同 時に要素技術の高度化も達成される。ビジネス的にもアッ プグレードサービスや種々のコンテンツサービスが可能と なり，アイディアを持ったベンチャー企業などの新規参入 機会も拡大される。さらに，ORCA は基本的にはソフト ウェアの枠組みであるが，これに対応する CPU ボードの 開発も進めている。最終的には, 実装化に向けて小型化, 低消費電力化のために, システム LSI の開発まで広がっ ていく可能性がある。

\section{4. ホームユースロボットの技術とその課題}

ここでは, 先に述べたようにロボットとしての基本機 能, 情報家電機能, セキュリティ機能について, その技術 を紹介する。

\section{1 基本動作：画像・音声・運動制御の融合技術}

ホームユースでは，ロボットが人のそばまで来てくれ る, あるいは人の方に向いてくれる, というのが基本動作 である。“呼べば来る”動作を実現するためには, 図 3 に 示すように，まずロボットが呼ばれると，音源推定により お打む社のした方向にカメラを向けて，その画像の中か ら人の顔を探す。次に顔が見つかれば，登録された顔の中 から顔認証を行い, だれが呼んだのかを特定する。そして 検出した顔の方向や大きさ, カメラの画角・向きから, 呼 んだ人までの距離を推定して, 障害物を回避しながらそば まで移動する。ここで初めて，ロボットが呼んだ人にいろ いろなサービスを行うことができる。さらに，家族のだれ が呼んだのか分かれば家族の趣向に応じた，より気の利い たコンテンツサービスを提供することも可能となる。この 


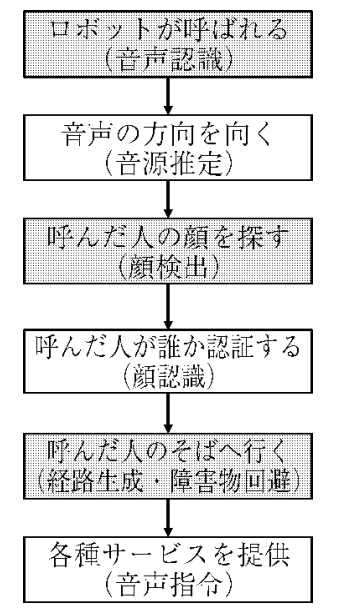

図 3 “呼べば来る”の処理フロー

ように，呼べば来るだけでも個々の要素技術がシームレス に融合される必要がある。

また，ロボットと人との位置が生活環境下で変化するこ とで, ロボットならではの課題が生ずる。移動するには家 庭内の環境地図も必要となり, 地図の生成方法や自己位置 の推定方法などの課題もある。逆に移動ロボットであるか ら，音声や画像などを認識しやすい位置へ移動することも できる。場合によっては人の方から歩み寄ることもあり得 る。このように, 音声・画像・運動との融合により新しい 認識技術や制御技術も開発される可能性がある。サービス コンテンツを載せていくためには，まずロボット本体があ る程度の自律・自立性を有していなければならない。そし て技術レベルに応じて段階的に用途や製品化を考える必要 がある。

\section{2 情報家電機能：ネットワーク技術, インタフェー ス技術}

現在，家庭内ではいろいろなネットワークが存在してい る。家電接続の ECHONET ${ }^{\mathrm{TM} \text { 注1 }}$ やAV 機器の IEEE 1394, パソコンなどの有線/無線 LAN, 電話線などがある。 ECHONET $^{\mathrm{TM}}$ では家電がネットワークでつながり, 家電 の操作や状態の管理を行うことができる。ApriAlpha ${ }^{\mathrm{TM}}$ からこのようなネットワーク機器へアクセスするために,

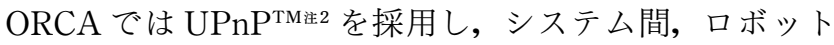
内のモジュール間の自動接続を実現している。 $\mathrm{UPnP}^{\mathrm{TM}}$ は，物理的なネットワークメディアやソフトウェアプラッ トフォームに非依存, 標準のインターネット技術がベー ス, といった技術的特徴を持ち, ロボットが家電機器と連 携する際などのネットワークインタフェースとして適して いる。

\footnotetext{
萧1 ECHONET は, エコーネットコンソーシアムの商標

注2 UPnP は, UPnP Implementers Corporation の商標または証明 マーク
}

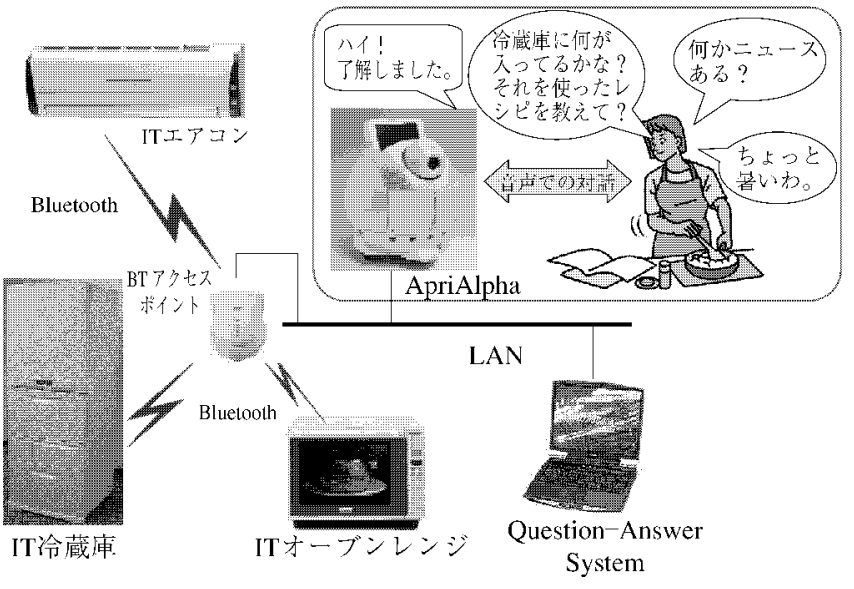

図 4 ホームユースロボットとネットワーク家電との連携

図4 に ApriAlpha ${ }^{\mathrm{TM}}$ とネットワーク家電と連携したシ ステム構成を示す。冷蔵庫・エアコン・電子レンジが Bluetooth ${ }^{\mathrm{TM} \text { ia }}$ アクセスポイントを介し, LANに $\mathrm{UPnP}^{\mathrm{TM}}$ で接続している。これらの機器はネットワークに つなげれば，UPnP $\mathrm{UM}^{\mathrm{TM}}$ の機能を用いて自動的に相互に認識 される。また，コントローラのプログラムは $\mathrm{UPnP}^{\mathrm{TM}} を$ 利用して記述でき, 機器カテゴリー別の依存なく, また, 家電・ロボットの区別なく, 双方向的に記述できる。

次に異機種家電の自動接続機能，ニュースを検索するエ ージェント機能，質問応答機能を組み合わせたシステム検 証を行った。例えば，ユーザは料理をしながら，「何かニ ュースある?」とロボットに聞けば, エージェント検索機 能によりインターネットから最新ニュースが確認でき, 「ちょっと暑いわ」と言えばネットワーク経由でエアコン を自動で調整し，「冷蔵庫に何が入っているかな？」と言 って冷蔵庫の中を確認し，「それを使ったレシピを教えて」 と聞けばロボットがレシピ質問応答システムにより，レシ ピを検索して教えてくれる。調理をしている途中でも，レ シピ内容に関して音声で質問ができる。また，電子レンジ へのレシピ情報の設定や, 調理終了の通知なども可能であ る。将来，このようにロボットとの簡単な対話だけで，異 種かつ複数機器に対して複雑なリモコン操作なしに, 料理 などいろいろな仕事ができるようになるだろう。そのため には, 各社の家庭内機器がつながる共通のプロトコルやプ ロファイル化が必要である。RoboLink やロボットサービ スイニシアチブなど, すでに異機種ロボットにおいて共通 のサービスを行う取り組みも始まっている(6)(8)。

\section{3 セキュリティ機能: 通信・ナビゲーション技術, センシング技術}

セキュリティ機能の一つとして，あらかじめ決められた

\footnotetext{
«3 Bluetooth は, Bluetooth SIG, Inc. の商標
} 
場所を見に行く巡回機能が挙げられる。指定された場所へ 行って, 搭載しているカメラで撮った画像を外出中のユー ザに送る。異常があれば携帯やサービスセンタに通知す る。ApriAlpha ${ }^{\mathrm{TM}}$ ではウェブサーバ機能を持たせ，ユー ザがホームネットワークに接続した携带情報端末 （PDA）や，インターネットに接続した携带電話のウェブ ブラウザからアクセスすることで，ロボットを遠隔操作し 搭載カメラの画像を確認することができる。 MPEG-4 な ぞ画像圧縮技術を用いれば，動画によるやり取りも可能で ある。さらに，異常音が定義できれば，ドア・空センサや ガラスの割れる音などから異常を検出して，登録された携 帯電話への通知なども可能となる。また，ユーザ側からも 携帯電話を使い，ズームも含めてカメラアングルの調整や ロボットの走行制御が可能であり, 必要な時に必要な場所 を見に行くことができる。ただし，ロボットは多機能化が 可能であるが，ネットワーク上の一つのデバイスでもあ る。安全・安心への信頼性をより高めるには，ホームセキ ユリティサービスなどと併用することが考元られる。

\section{5. 環境デザインとロボット}

ロボットでできることは限られているが，その性能向上 には切りがない。それは，ロボットに人ができることと同 様なことを期待しているからである。しかし，ロボットは ネットワークとつながることで能力が拡大される。したが って, ロボットがたくさんのセンサを搭載したり, 高次処 理をロボット搭載の CPU で行う必要はなく，家の中にあ るドア・空センサや，人感センサ・火災センサを使った り，物体認識などの高次処理にはネットワーク側にあるデ ータベースの情報や CPU を使うことができる。

一方, ロボットは実体のある存在であり, 段差越え, 障 害物回避, ドアの開閉, 空の開閉など, 物理的に困難な作 業も数多くある。移動することを考えると，家庭内では 精々一つの部屋内を移動する程度であり, 博物館など施設 内で移動や安全のための技術を蓄積することが現実的であ る。公共施設や住宅のバリアフリー化は進んでおり，これ らはロボットにとっても効果があり，環境が整うことでロ ボットの作業性は飛躍的に向上する。図 5 に示すようにす でに家庭に扔いても情報的な環境は整いつつあり，今後は ロボットが動作する物理的な環境も整備する必要がある。 ユニバーサルデザインというとだれでもが使えるデザイン であるが，ここでロボットにも使えるデザイン（UDR： Universal Design with Robots と呼ぶ）が重要になってく る。移動ばかりでなく，把持すること，見ることにおいて もロボットにもやさしいインタフェースがあると考えてい る。

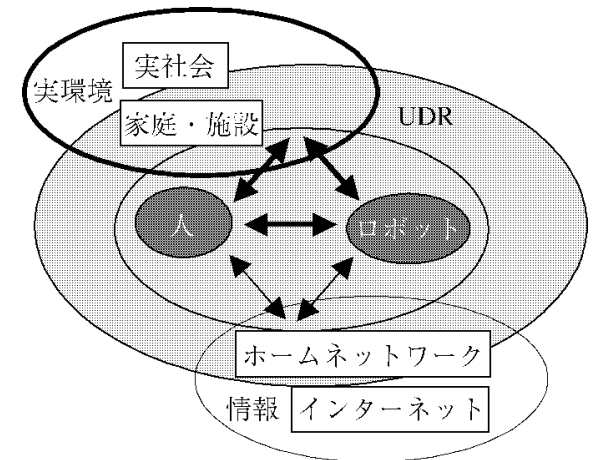

図 5 情報と実環境とのインフラとロボット

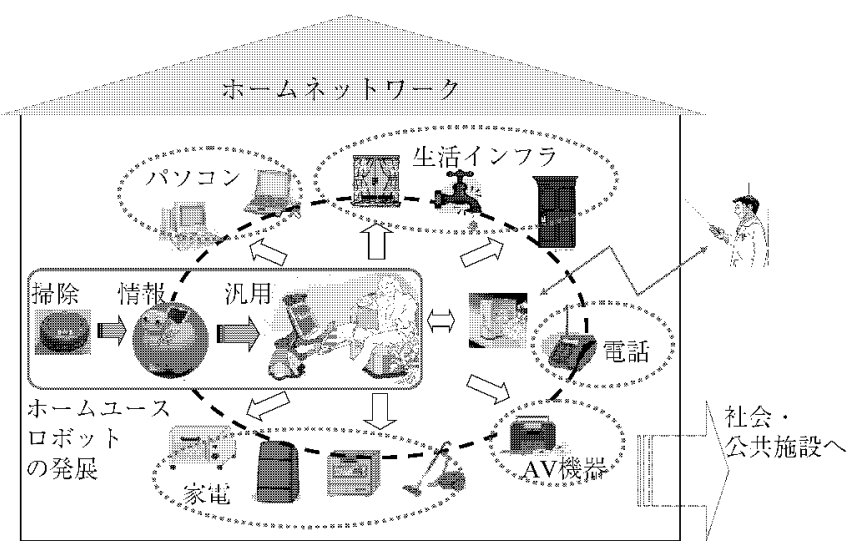

図 6 ネットワーク環境で要となるホームユースロボット

\section{6.おわりに}

本稿では，ホームユースロボットへの期待およびロボッ 卜の自律化，実用性が高いと考えている情報家電・セキュ リティ応用について技術と課題を述べた。さらに，ロボッ 卜技術（RT）が普及するためのオープン化・標準化によ る広範囲なビジネス機会の拡大，またロボットが生活環境 下で動くための環境のデザインについて述べた。今後, ホ ームユースロボットは, 図 6 亿示すように単機能・多機能 化，情報家電化，沉染化と展開されていくだろうが，早期 にネットワーク環境で家庭内機器の要となるように，一つ 一つ課題を解決していきたい。

(平成 17 年 1 月 25 日受付)

（1）「特集 生活支援ロボット」，ロボット，147，pp. 2-42（2002）

（2）「特集 清掃・留守番・セキュリティロボット」， ロボット， 152, pp. 1-26 (2003)

(3)「特集 ホームロボット技術」, 東芝レビュー, 59, 9, pp. 2-40 (2004)

（4）日経産業新聞, 2003 年 1 月 9 日. 2004 年 1 月 28 日

(5)「特集 国及び地方自治体等のロボット産業振興策」, ロボット, 159, pp. 2-16 (2004)

（6）「特集 RT ミドルウェアプロジェクトとRTオープン化の開発 事例」、ロボット, 153, pp. 1-28（2003）

( 7 ) http://www.horb.org/horb-j

( 8 ) http://www.robotservices.org 